\title{
ANALYSIS OF MODERN REHABILITATION METHODS FOR BRIDGES AND OVERPASSES
}

Meneylyuk A. I., Doctor of Engineering Science, Professor, meneilyk@gmail.com, ORCID: 0000-0002-1007-309X

Putilin S. V., post-graduate student, putilinstanislavsv@gmail.com, ORCID: 0000-0001-7104-2599

Odessa State Academy of Civil Engineering and Architecture

\begin{abstract}
Nowadays in Ukraine there is a situation where 27\% of examined bridges require immediate rehabilitation, and $63 \%$ did not meet the requirements of actual codes. More than half of the existing bridges and overpasses are not examined in normative terms, and information on their technical condition is not actual or missing. Therefore, the objective of the research is an analysis of the ways to restore the damaged elements of construction of reinforced concrete bridges and overpasses to select effective solutions.

To achieve this objective, the methods of systematic and structural analysis and synthesis, generalization and classification, abstraction and formalization, combinatory morphological analysis and synthesis are used to determine the restoration method.

In the article we have provided the analysis and classification of defects, which are most often found during the examination of concrete bridges and overpasses. They are a failure of waterproofing on roadway pavements and pedestrian sidewalks, spalling of concrete, corrosion of reinforcement, concrete corrosion, cracks, and manufacturing structure defects, mechanical damage resulting from transportation, installation and operation.

After the analysis of the most common damages, the results of basic methods of reconstruction of bridges and overpasses analysis are presented. The main ways to restore the pillars, girders of span structures and paving the roadway structures are observed. To determine the ways of each methods usage defined they are reviewed by their positive and negative characteristics.

It is shown that for designing the project of restorative works it is required to select the most effective solution for each of the damaged structural elements of the bridge. It is concluded that this technique can be determined through multi-criteria analysis. Therefore, it is an object of further research to conduct a multi-criteria analysis of the described methods with the specific conditions for each construction, survey the results and compare them by basic parameters.
\end{abstract}

Keywords: bridge, overpass, defect, technologies, reinforced concrete, ways of rehabilitation.

Introduction. Close to $27 \%$ of the examined bridges and overpasses require immediate rehabilitation, $63 \%$ do not comply with the code requirements [1]. For more than half of the maintained bridges and overpasses, there is no objective and up-to-date information on their condition. The abundance of existing solutions and the absence of recommendations on the selection of effective rehabilitation methods in the reviewed codes and regulations determine the necessity to analyze the main defects and methods of structural elements reconstruction. Therefore, the article is devoted to the analysis of the main defects and the methods for their elimination. This analysis will allow for the objective evaluation of the rehabilitation methods and the selection of the most effective ones for the future repairs and creation of the safe comfortable operational conditions for bridges and overpasses.

Objective of the article. For the selection of effective solutions, it is required to analyze the methods for repairing damage to structural elements of reinforced concrete bridges and overpasses.

To achieve this objective, the following tasks have been solved:

- the analysis of the damages most commonly encountered while examining bridges and overpasses; 
- the analysis of the damage repair methods;

- the detection of positive and negative properties of technologies and materials to determine their rational domain of application.

Research method. The methods of systematic and structural analysis and synthesis, generalization and classification, abstraction and formalization, combinatory morphological analysis and synthesis are used in the research to determine most useful rehabilitation methods.

Research results. In this work, damages are seen as deviations from the original quality level of the elements and structures of the construction that occurred in transportation, erection, accident and/or operation [2].

The bridge is a structure for providing passage for transport or pedestrians over a river or other water obstacles (lake, swamp, strait) [2].

Overpass is a structure designed to provide passage for traffic streams that intersect [2].

Hereafter in the article, bridges are meant by both bridges and overpasses.

Rehabilitation in this work is understood as a set of civil construction and erection works aimed at restoring the design parameters of the structure or the renovation of the structure with giving it new service parameters.

Bridges are an important part of Ukraine's infrastructure. They are designed to provide safe passage of vehicles, pedestrians, utility lines over obstacles. When in service, their structures are exposed to operational loads and aggressive environments. As a result, the structures get damaged and deprived of their original properties. Bridge closures bring up various social issues and economic losses.

Most Ukrainian road bridges were built with the use of standard precast concrete structures (89.3\%). In service on automobile roads, there are also bridges with metal and steel-reinforced concrete spans $(5.9 \%)$, wooden bridges make up about $1 \%$ [3].

As for 01.01.2013 [4] in Ukraine 16187 units of road bridges are subordinate to UkrAvtodor. As for 01.01.2016 the AESUM (Analytical Expert Bridges Management System) database contains up-to-date information on the engineering status of 6919 bridges, of which 1873 require immediate repairs for further safe operation. For 9268 units of bridges, the technical condition is not determined. The causes for the poor maintenance condition of the bridges are man-triggered (exceeding of the bridge structural design load due to the intensification of the traffic stream and increase in the weight of modern vehicles, traffic accidents, etc.), natural (aggressive medium, moisture, variations of water level, solar radiation, etc.) and socio-economic factors (lack of funds for inspection, maintenance or repairs, military actions, etc.) [5].

The rehabilitation of damaged reinforced concrete bridges and their further safe operation can be divided into five stages:

- regular inspection of the technical condition of the construction;

- logistical preparation for the construction rehabilitation;

- designing a project for renovation works;

- renovation works;

- monitoring of the construction technical condition after rehabilitation.

At the first stage, as a result of the monitoring, the existence of defects and damages, the causes and the damage state of the construction are determined, the decision is taken on the need for eliminating the damages.

Existing technical condition analysis of reinforced concrete bridges shows that the most common damages are [6]:

- waterproofing failures on traffic and pedestrian ways;

- concrete spalling;

- reinforcement corrosion;

- concrete corrosion;

- cracks;

- imperfections arising from structure fabrication;

- mechanical defects arising from transportation, erection and maintenance. 
The examples of the most common damages discovered during inspections are shown in Fig. 1-3.

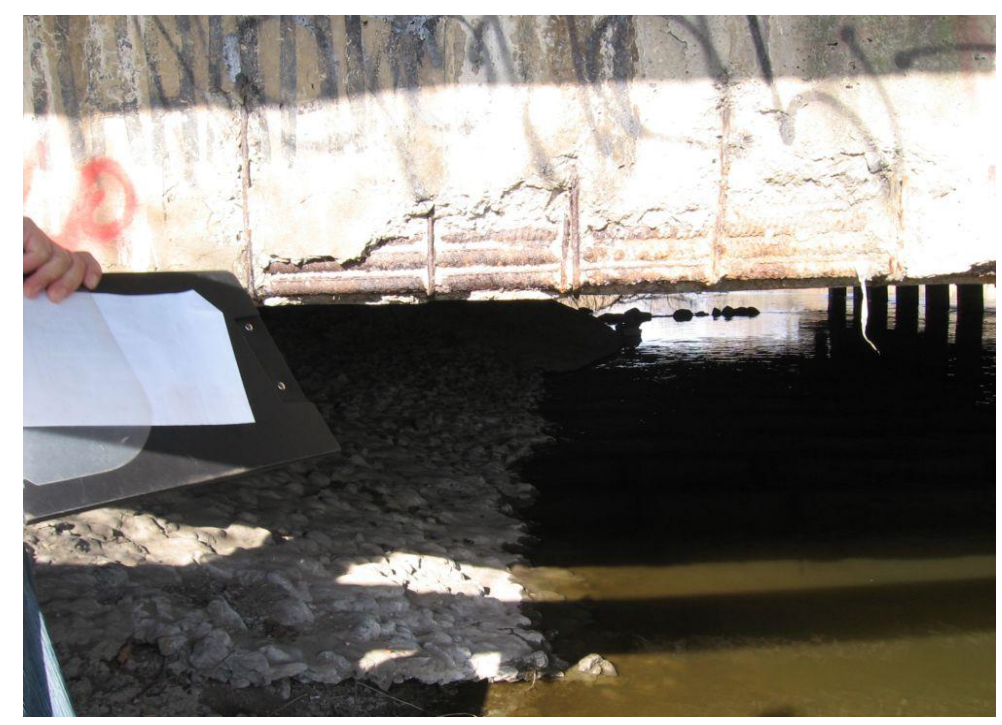

Fig. 1. Concrete spalling, exposed and corroded reinforcement of the bridge deck girders

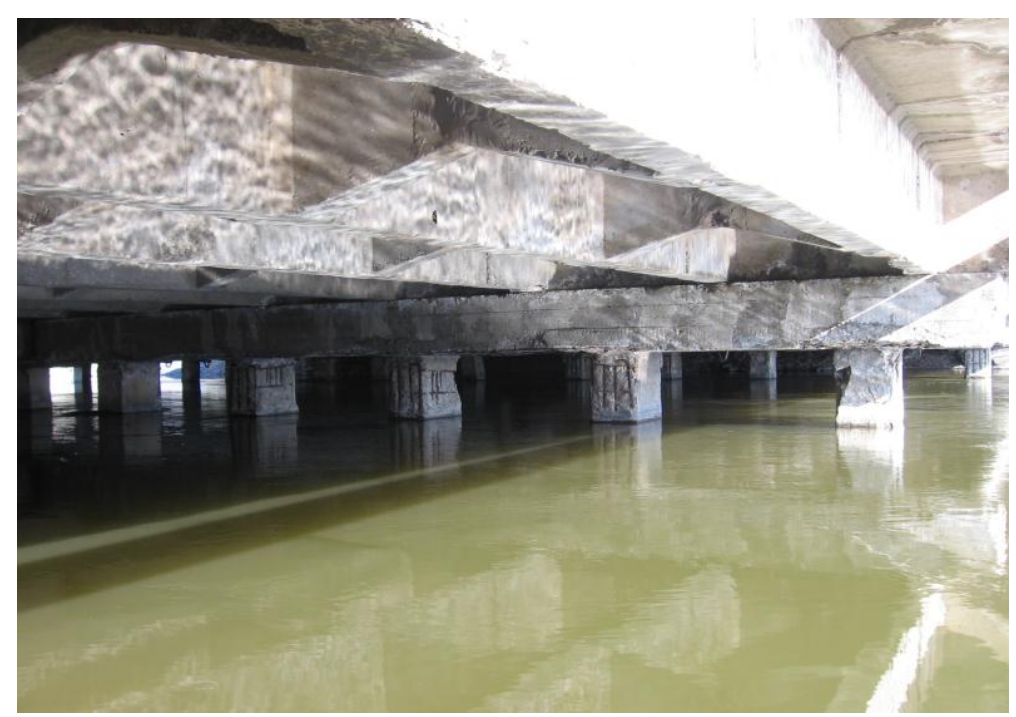

Fig. 2. Concrete spalling, exposed and corroded reinforcement of the bridge piles

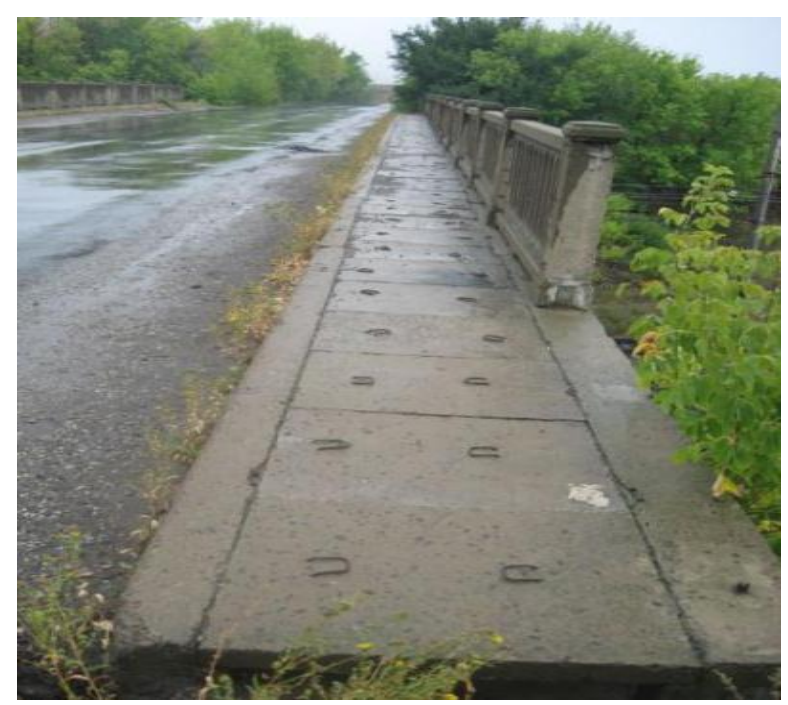

Fig. 3. Partial lack of bridge railing and damages of the road dressing 
The damages of bridge structures can be conventionally classified by the following features:

1. By location on the bridge structural elements.

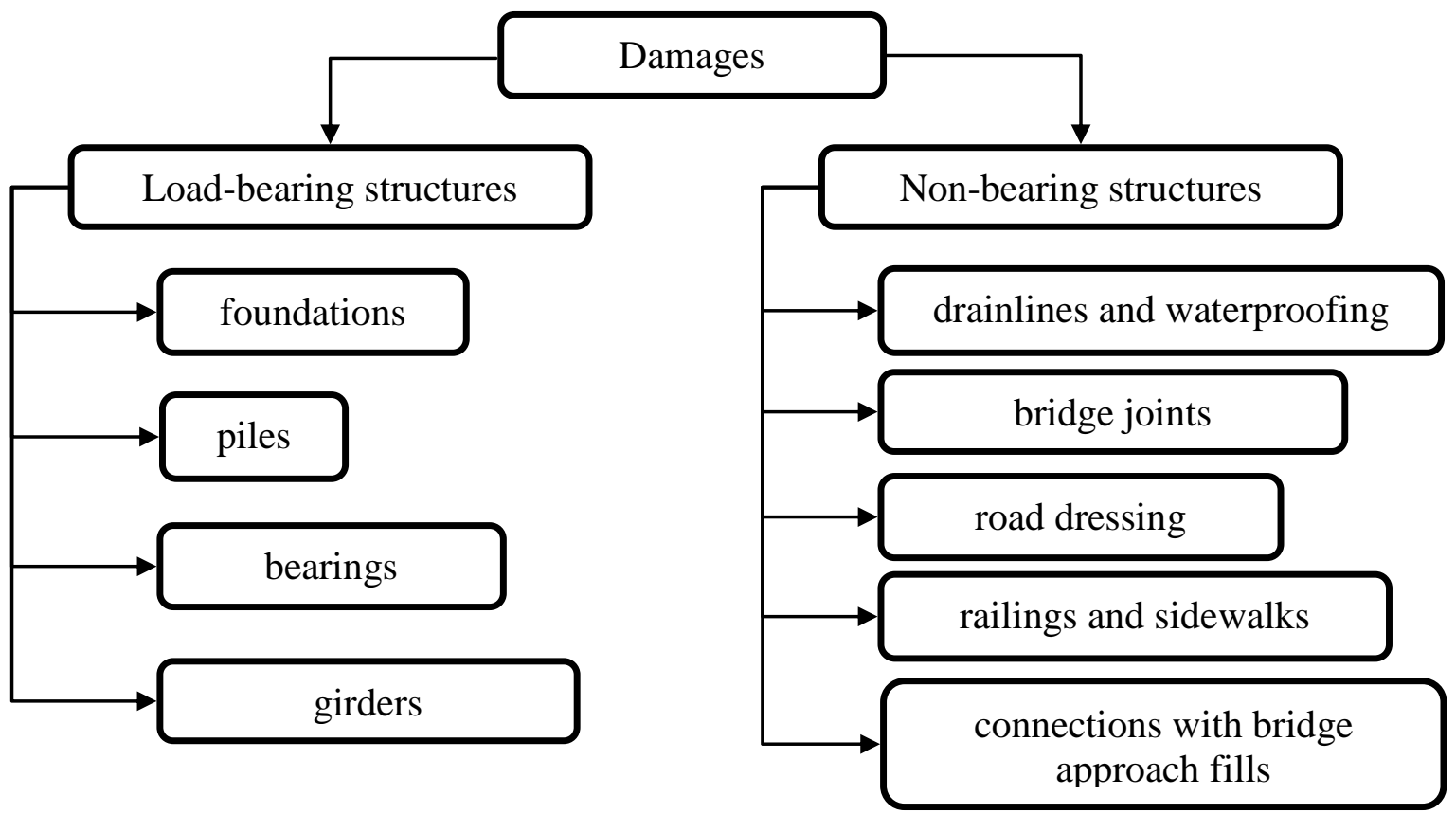

Damages to the load-bearing structures affect the bridge capacity, life of the structure and safety of movement on the bridge. Damages to the non-bearing structures affect the life of the structure and safety of movement on the bridge.

2. By rate of growth into a dangerous condition [6]:

- instantly growing;

- fast growing;

- gradually growing.

3. By degree of hazard [6]:

- high-hazard;

- hazardous;

- low-hazard.

At the second stage of rehabilitation, which is logistical preparation for restoring of the construction, the preliminary gathering of information, the analysis of the maintenance history, pilot survey and Front End Engineering Design are conducted. As a result, the technical condition of individual structures and the feasibility of their renovation are determined.

After that, the overall bridge rehabilitation project is designed, following which effective construction solutions and work practices should be selected.

The renovation of foundations and underwater parts of the bridge pillars is executed only under special projects after a detailed survey of these structures. The renovation of the underwater parts of foundations is reviewed in these works [3, 7-10]. The most common method is cast concrete jacketing. The reinforced concrete jacket can be made by in-water method or with unwatering.

The renovation and strengthening of the above-water parts of the bridge pillars can be performed by such design and technology solutions:

- by reinforced concrete belts;

- by metal casting;

- by composite materials;

- by cementation (for pillars that have a big number of internal defects);

- by reinforced concrete jackets.

The method of increasing the load-carrying capacity of the pillars with reinforced concrete belts is used in case there are horizontal and/or vertical and diagonal cracks. The height of such 
belts is $1-1.5 \mathrm{~m}$ and the width is $25-40 \mathrm{~cm}$. They are armored with bar reinforcement grids $25 \mathrm{~mm}$ in diameter, which are fastened with mechanical shear connectors $18-25 \mathrm{~mm}$ in diameter, driven to the depth of 50-75 cm [8].

The advantages of this method are that it doesn't require:

- high-technology material and equipment;

- specialized work performers.

The disadvantages of this method are:

- large proper weight of the reinforcing elements;

- high labor inputs.

Strengthening the pillars with metal casting is temporary and is applied in the emergency state of the construction. It consists of rolled metal itself and pull-bars with socket screws [3].

The advantages of this method are that it doesn't require:

- not high labor intensity;

- shorter period of work execution.

The disadvantages of this method are the following:

- not long service life;

- need for renewing anti-corrosion coatings.

For strengthening the pillars, composite materials may be used. The method is implemented by attaching composite lamellas or fabrics to the existing structure by means of polymer enhanced adhesives or a mineral-based binder.

The advantages of this method are the following:

- low proper weight of the composites;

- composites are resistant to corrosion and do not require additional renewable protection;

- simple technological procedures while performing works on strengthening.

The disadvantages of this method are the following:

- high cost of materials.

The cementation method consists in injecting cement mortar under 0.1-1.5 MPa into $36-75 \mathrm{~mm}$ holes spaced at intervals of 0.9-1.5 m [3].

The advantage of this method is the improvement of water impermeability and the elimination of water travel through the masonry.

The disadvantages of this method are the following:

- need for special equipment;

- high labor inputs.

The 'jacket' is strengthened with reinforcement grids $20-25 \mathrm{~mm}$ in diameter, which are attached to steel anchors $20 \mathrm{~mm}$ in diameter deepened into the pillar body by $16-20 \mathrm{~cm}[3,8]$.

The advantages of this method are that it doesn't require:

- high-technology material and equipment;

- specialized work performers.

The disadvantages of this method are the following:

- large proper weight of the reinforcing elements;

- high labour inputs.

The renovation and strengthening of the reinforced concrete substructures can be performed through the following design and technology solutions:

- by growing the section with additional reinforcement;

- with rolled sheet metal;

- with composite materials;

- by changing the structural design with the help of tie pieces, strut-framed beam, truss bars, additional supporting attachments that reduce the load on the existing structure.

Strengthening by means of section growing supposes that the structure being reinforced is to be enlarged height or width along (from below, from the sides or from the top of the element being reinforced).

To raise the load-bearing capacity of the elements, which are being strengthened, by means of 
section growing, it is sufficient to increase the amount of the main reinforcement. For this, the protective layer is spalled off by at least 0.5 diameter of the reinforcement. Then the additional reinforcement is spliced with the existing one. To do this, bearing blocks are welded from reinforcing rods 10 to $40 \mathrm{~mm}$ in diameter and 50 to $200 \mathrm{~mm}$ in length $[3,8]$. The scheme of strengthening is presented in Fig. 4.

The advantages of this method are that it doesn't require:

- high-technology material and equipment;

- specialized work performers.

The disadvantages of this method are that it produces an insignificant effect on increasing the load-bearing capacity and requires considerable labor input.

Alternatively, to increase the load-bearing capacity, growing of the height of the normal cross-section can be applied. Such type of strengthening is performed in the form of a reinforcement cage, consisting of longitudinal and transverse rods and stirrups welded to the existing reinforcement. This type of strengthening is presented in Fig. 5.

The advantages of this method are the following:

- no need for high-technology material and equipment;

- no need for specialized work performers;

- high reinforcement increment $40 \%$.

The disadvantages of this method are the following:

- significant enlargement of the structure size;

- large proper weight of the reinforcing elements;

- high labour inputs.

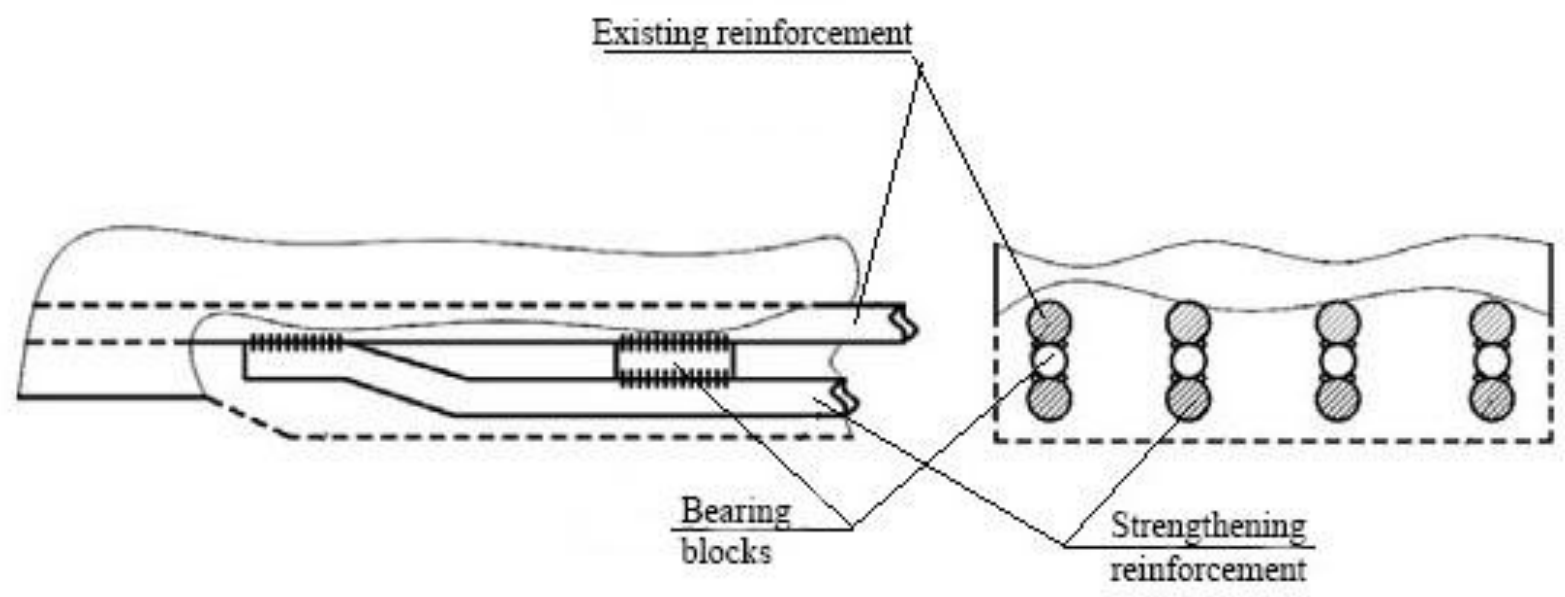

Fig. 4. Strengthening of the bridge girders with additional reinforcement

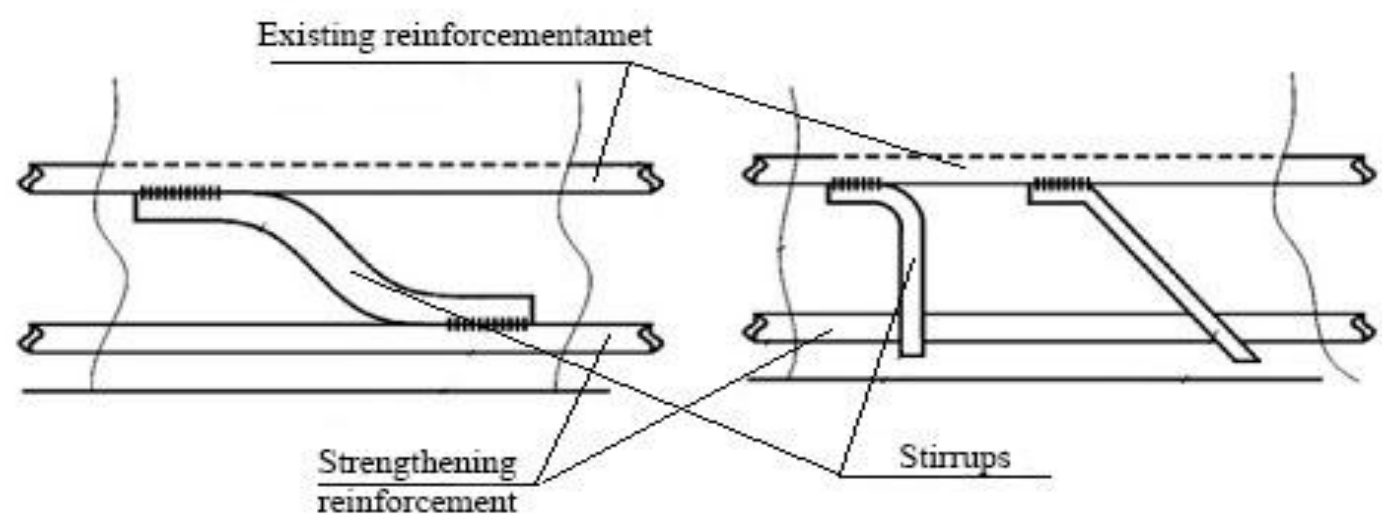

Fig. 5. Strengthening of the bridge girders with reinforcement cage 
Strengthening with rolled sheet metal apart from the sheets themselves consists of inclined and vertical pull-rods, connecting strips and support plates [3, 8].

The advantages of this method are the following:

-no need for high-technology equipment;

- strengthening efficiency is $35-50 \%$ (compared with the strength properties of the girder prior to strengthening).

The disadvantages of this method are the folowing:

-need to provide for additional protection of the rolled sheet metal from corrosion;

-high cost;

-need for painstaking quality control of the weld seams.

A promising method now is strengthening of bridge spans with composite materials. It is implemented through attaching composite lamellas or fabrics to the existing structure with polymer adhesives or mineral-based binders. As an option, it is possible to install bar composite reinforcement into specially designed indenting filled with adhesive.

The advantages of the composite materials are the following [11]:

- high tensile and compressive breaking;

- resistance to aggressive medium;

- easy to transport and install.

The disadvantages of the composite materials are the following:

- relatively high cost;

- low fire resistance;

- narrow temperature ranges for work performance $\left(+10^{\circ} \mathrm{C}\right.$ до $\left.+30^{\circ} \mathrm{C}\right)$.

The repairs of waterproofing of the road dressing and sidewalks of the constructions under consideration are divided into four types, depending on their condition $[3,9]$ :

- spot repairs of waterproofing in adjoining places of the safety fence, joints, on sidewalks, as well as on the traffic way (if the area of the damaged waterproofing does not exceed $20 \%$ of the area of the traffic way);

- repairs of the waterproofing lengthwise the span on the sidewalks, if the length of the damaged area is up to $20 \%$ of the bridge length;

- repairs of the waterproofing along the full length of the traffic way, if damages take more than $20 \%$ of the waterproofing area (without repairs on the sidewalks);

- general repairs of the waterproofing, including sidewalks.

For the waterproofing repairs, there are the following methods:

- waterproofing with the use of bituminous and rolled materials [3];

- waterproofing with a leveling course of concrete on expansive cement (with a large number of open concrete cracks) [9];

- surface waterproofing with the use of XC-710 perchlorvinyl enamel and SPRUT adhesive [12];

- waterproofing with the use of mastics with a thermal protective layer [13].

Repair of expansion joints can be divided into three types:

- preventive repairs - blowing-down, washing, and cleaning the joints and cunettes of dirt, updating mastic, bolt tightening;

- repairs and replacement of individual elements of rubber expansion joints, sliding plates and similar;

- complete replacement of structures.

The choice of a particular type of repair depends on the damage category.

Technologies for the renovation of expansion joints with rubber elements, joints of buried, coped and strip seal types are described in $[12,14,15]$.

When eliminating local potholes, subsidences and corrugations, the infrared spot repairs technology is used $[3,9]$.

If the road dressing has a considerable number of irregularities, pits, cross fall defects, hot inplace recycling method is used for restoring the bituminous concrete pavement, hot in-place 
recycling method is performed using one of the following technologies $[3,9,12]$ :

- thermal planning;

- thermal paving;

- thermal mixing;

- thermal plastification.

The method of thermal planning consists in leveling and restoring of the original shape of the roadway. For this the old bituminous concrete pavement is heated up. Then it has to be loosened, mixed, re-paved and compacted without any additives (crushed stone, plastifiers, new bitumenconcrete mix).

The method of thermal paving consists in renovating the road surface by adding new bitumenconcrete mix. The specific feature of the thermal paving method is that the new mixture is not mixed with the old one, but is paved on top of the layer that is being restored.

The method of thermal mixing consists in restoring the lost bituminous concrete pavement by adding new asphalt mix, crushed stone, bitumen binder and plastifiers.

To reduce the brittleness of asphalt concrete, the method of thermal plasticification is used, the essence of which is to add a plastifier to the mix, which is being regenerated, without adding new asphalt mix.

The advantages of the hot in-place recycling method are the following:

- the taken up asphalt mix is $100 \%$ recycled;

- no need to close the site where works are being performed.

The main disadvantage of the hot in-place recycling method is that its application is limited by the heat-up depth of $3-5 \mathrm{~cm}$. To this depth, the layer being regenerated gets solidified. If the pavement strength is insufficient, which is usually shown in numerous cracks or cracking patterns randomly located on the pavement, the hot in-place recycling method, as a rule, are not used, since reflective cracks soon appear on the regenerated pavement.

The analysis shows that there are many ways and design and technology solutions for the rehabilitation of bridges. Working out a plan of restorative work requires selecting the most effective solution for each structural element of a bridge. One of the ways to solve the problem of choosing effective methods is the multi-criteria analysis technique with the use of modern software products, such as pivot tables and charts in Excel.

Therefore, the objective for further research is to conduct a multi-criteria analysis of the reviewed methods and to select the most effective solutions for the surveyed bridges.

\section{Conclusions:}

1. On public roads, about $27 \%$ of bridges require immediate restoration, and $63 \%$ do not meet the code requirements.

2. The analysis conducted shows that various technologies and materials are used to restore the structural elements of bridges and overpasses.

3. To select the most effective recovery methods, it is necessary to perform a multi-criteria analysis of possible solutions, taking into account particular conditions for each structure and the survey results, and compare them for the core indicators.

\section{References}

[1] Mosty i truby. Osnovni vymohy proektuvannya: DBN V.2.3-22:2009. K.: Minrehionbud Ukrayiny, 2009.

[2] Mosty ta truby. Obstezhennya i vyprobuvannya: DBN V.2.3-6:2009. K.: Minrehionbud Ukrayiny, 2009.

[3] Y.Y. Luchko, P.M. Koval', Mosty : konstruktsiyi ta nadiynist'. L'viv : Kamenyar, 2005.

[4] O.O. Davydenko, "Statystychnyy prohnoz tekhnichnoho stanu avtodorozhnikh mostiv Ukrayiny", Mosty ta tuneli: teoriya, doslidzhennya praktyka, zbirnyk naukovykh prats' Dnipropetrovs'koho natsional'noho universytetu zaliznychnoho transportu, Vol. 10, pp. 4-10, 2016.

[5] O.Y. Trufanova, L.V. Fes'kova, "Analyz faktorov, vlyyayushchykh na nadezhnost' y 
tekhnycheskye kharakterystyky zhelezobetonnykh puteprovodov", Mosty ta tuneli: teoriya, doslidzhennya, praktyka, zbirnyk naukovykh prats' Dnipropetrovs'koho natsional'noho universytetu zaliznychnoho transportu, Vol. 7, pp. 81-89, 2015.

[6] Ye.A. Dmitrenko, N.V. Pochtar, "Osnovnyye tipy defektov i povrezhdeniy zhelezobetonnykh konstruktsiy transportnykh sooruzheniy, prichiny ikh vozniknoveniya", Zb. nauk. pr. "Budivli ta konstruktsiyi iz zastosuvannyam novykh materialiv ta tekhnolohiy", Vol. 3, pp. 134-138, 2016.

[7] A.V. Kokodeyev, I.G. Ovchinnikov, "Obsledovaniye, monitoring, vypolneniye remontnykh i vosstanovitel'nykh rabot na podvodnykh chastyakh transportnykh sooruzheniy", Internetzhurnal "Naukovedeniye", Vol. 5, pp. 1-36, 2014.

[8] V.A. Dement'yev, V.P. Volokitin, N.A. Anisimova, Usileniye i rekonstruktsiya mostov na avtomobil'nykh dorogakh. Voronezh: Voronezh. gos. arkh.-stroit. un-t., 2006.

[9] N.YE. Strakhova, V.O. Holubyev, P.M. Koval'ov, V.V. Todirika, Ekspluatatsiya $i$ rekonstruktsiya mostiv. K.: Transportna akademiya Ukrayiny, 2002.

[10] V.O. Osipov, Soderzhaniye i rekonstruktsiya mostov. M.: Transport, 1986.

[11] A.I. Meneylyuk, T.M. Dubel't, I. A. Meneylyuk, Innovatsii v stroitel'stve i rekonstruktsii. K.: TOV NVP "Ínterservís", 2018.

[12] Rukovodstvo po remontu elementov mostovogo polotna avtodorozhnykh mostov. M.: TSBNTI Minavtodora RSFSR, 1989.

[13] Instruktsiya po ustroystvu gidroizolyatsii konstruktsiy mostov $i$ trub na zheleznykh, avtomobil'nykh $i$ gorodskikh dorogakh: VSN 32-81. M.: Ministerstvo transportnogo stroitel'stva, 1982.

[14] Rekomendatsii po remontu $i$ ukhodu za deformatsionnymi shvami $v$ malykh $i$ srednikh mostakh. M.: TSBNTI Minavtodora RSFSR, 1989.

[15] Deformatsionnyye shvy mostovykh sooruzheniy na avtomobil'nykh dorogakh: ODM 218.2.025-2012. M.: Rosavtodor, 2013.

\title{
АНАЛІЗ СУЧАСНИХ СПОСОБІВ ВІДНОВЛЕННЯ МОСТІВ ТА ШЛЯХОПРОВОДІВ
}

\author{
Менейлюк О. І., д.т.Н., професор, \\ meneilyk@gmail.com, ORCID: 0000-0002-1007-309X \\ Путілін С. В., аспірант, \\ Одеська державна академія будівництва та архітектури \\ putilinstanislavsv@gmail.com, ORCID: 0000-0001-7104-2599
}

\begin{abstract}
Анотація. В Україні на даний час з обстежених мостів 27\% вимагають негайного відновлення, а 63\% не задовольняють вимогам діючих нормативних документів. При цьому більше половини існуючих мостів і шляхопроводів не обстежені в нормативні терміни, а відомості про їх технічний стан застарілі або відсутні. Тому мета дослідження - аналіз способів відновлення пошкоджених конструктивних елементів залізобетонних мостів та шляхопроводів для вибору ефективних рішень.

Для досягнення поставленої мети в роботі використані методи системно-структурного аналізу і синтезу, узагальнення і класифікації, абстрагування та формалізації, комбінаторноморфологічного аналізу і синтезу для визначення раціональних способів відновлення.

У статті виконано аналіз і складена класифікація дефектів і пошкоджень, які найбільш часто виявляються при обстеженні залізобетонних мостів i шляхопроводів. Ними є: порушення гідроізоляції на проїзній частині і пішохідних тротуарах, відколи бетону, корозія арматури, корозія бетону, тріщини, дефекти виготовлення конструкцій, механічні пошкодження отримані в результаті транспортування, монтажу та експлуатації.

Після аналізу пошкоджень, які найбільш часто зустрічаються, в роботі представлені результати аналізу основних способів реконструкції мостів і шляхопроводів. Розглянуто основні способи відновлення опор, балок прогонових будов і покриття дорожнього полотна розглянутих споруд. Для визначення області раціонального застосування кожного із способів
\end{abstract}


в роботі визначені їх позитивні і негативні властивості.

У роботі показано, що для складання проекту відновлювальних робіт потрібно вибрати найбільш ефективне рішення для кожного пошкодженого конструктивного елементу моста. Зроблено висновок, що для цього можна використовувати методику багатокритеріального аналізу. Тому завданням подальших досліджень $є$ проведення багатокритеріального аналізу описаних способів з урахуванням конкретних умов для кожної споруди і результатів обстеження, і порівняння їх за основними показниками.

Ключові слова: міст, шляхопровід, дефект, технології, залізобетон, способи відновлення.

\title{
АНАЛИЗ СОВРЕМЕННЫХ СПОСОБОВ ВОССТАНОВЛЕНИЯ МОСТОВ И ПУТЕПРОВОДОВ
}

\author{
Менейлюк А. И., д.Т.н., профессор, \\ meneilyk@gmail.com, ORCID: 0000-0002-1007-309X \\ Путилин С. В., аспирант, \\ putilinstanislavsv@gmail.com, ORCID: 0000-0001-7104-2599 \\ Одесская государственная академия строительства и архитектурь
}

\begin{abstract}
Аннотация. В Украине в настоящее время из обследованных мостов 27\% требуют немедленного восстановления, а $63 \%$ не удовлетворяют требованиям действующих нормативных документов. При этом более половины существующих мостов и путепроводов не обследованы в нормативные сроки, а сведения об их техническом состоянии устарели или отсутствуют. Поэтому цель исследования - анализ способов восстановления поврежденных конструктивных элементов железобетонных мостов и путепроводов для выбора эффективных решений.

Для достижения поставленной цели в работе использован метод системноструктурного анализа и синтеза, методы обобщения и классификации, абстрагирования и формализации, комбинаторно-морфологического анализа и синтеза для определения рациональных способов восстановления.

В статье выполнен анализ и составлена классификация дефектов и повреждений, которые наиболее часто обнаруживаются при обследовании железобетонных мостов и путепроводов. Ими являются: нарушение гидроизоляции на проезжей части и пешеходных тротуарах, сколы бетона, коррозия арматуры, коррозия бетона, трещины, дефекты изготовления конструкций, механические повреждения полученные в результате транспортировки, монтажа и эксплуатации.

После анализа наиболее часто встречающихся повреждений в работе представлены результаты анализа основных способов реконструкции мостов и путепроводов. Рассмотрены основные способы восстановления опор, балок пролетных строений и покрытия дорожного полотна рассматриваемых сооружений. Для определения области рационального применения каждого из способов в работе определены их положительные и отрицательные свойства.

В работе показано, что для составления проекта восстановительных работ требуется выбор наиболее эффективного решения для каждого поврежденного конструктивного элемента моста. Сделан вывод, что для этого можно использовать методику многокритериального анализа. Поэтому задачей дальнейших исследований является проведение многокритериального анализа описанных способов с учетом конкретных условий для каждого сооружения и результатов обследования, и сравнение их по основным показателям.

Ключевые слова: мост, путепровод, дефект, технологии, железобетон, способы восстановления.
\end{abstract}

